\title{
ASSESSMENT OF CAFFEINE INTAKE WITH FOOD BY POLISH FEMALES AND MALES
}

\author{
Ewa Malczyk $k^{l}$ Joanna Wyka $a^{2}$, Agata Malczyk ${ }^{l}$, Katarzyna Larma ${ }^{l}$ \\ ${ }^{1}$ Department of Health Sciences and Physical Education, University of Applied Sciences in Nysa, \\ Armii Krajowej 7, 48-300 Nysa, Poland \\ ${ }^{2}$ Department of Human Nutrition, Wroclaw University of Environmental and Life Sciences, \\ Chełmońskiego 37, 51-630 Wrocław, Poland
}

\begin{abstract}
Background. Caffeine is the most widespread psychoactive substance in the world. With long-term consumption of caffeinated beverages, there is a high probability of overtaking on caffeine.

Objective. The aim of the study was to estimate the consumption of caffeine in the daily caffeine intake of Polish consumers, determine the caffeinated products in the intake of this substance.

Materials and methods. The survey was completed by 433 respondents living in Poland. The research tool was the electronic questionnaire, which consisted of: a) questions about personal data and measurement anthropometric and the level of physical activity and smoking; b) questions regarding the portion size and frequency of consumption of coffee, tea, cocoa, chocolate, energy drinks and colacarbonated beverages.

Results. The main sources of caffeine in the respondents' diet include: coffee (Me $43.64 \mathrm{mg} / \mathrm{d}$ ) and tea (Me $37.60 \mathrm{mg} / \mathrm{d})$. Approximately $20 \%$ of respondents exceeded the threshold of daily caffeine intake (safety level for children and adolescents up to $3 \mathrm{mg} / \mathrm{kg}$ b.w, for adults up to $5.7 \mathrm{mg} / \mathrm{kg}$ b.w), considered safe.

Conclusions. Respondents who have crossed the safe dose of caffeine intake, should limit the consumption of products being its main source (coffee).
\end{abstract}

Key words: caffeine, caffeine intake with food, Poland, women, men

\section{STRESZCZENIE}

Wprowadzenie. Kofeina jest najbardziej rozpowszechnioną substancją psychoaktywną na świecie. Przy długotrwałym spożywaniu napojów kofeinowych istnieje duże prawdopodobieństwo wystąpienia nadmiaru kofeiny.

Cel. Celem pracy było oszacowanie spożycia kofeiny w dziennym spożyciu kofeiny przez polskich konsumentów, określenie udziału produktów zawierających kofeinę w spożyciu tej substancji.

Materiały i metody. W badaniu wzięło udział 433 respondentów mieszkających w Polsce. Narzędziem badawczym był elektroniczny kwestionariusz ankiety, który składał się z: a) pytań dotyczących danych osobowych i pomiarów antropometrycznych oraz poziomu aktywności fizycznej i palenia tytoniu; b) pytań dotyczących wielkości porcji i częstości spożycia kawy, herbaty, kakao, czekolady, napojów energetycznych i napojów gazowanych.

Wyniki. Głównymi źródłami kofeiny w diecie respondentów były: kawa (Me 43,64 mg/d) i herbata (Me 37,60 mg/d). Około 20\% respondentów przekroczyło próg dziennego spożycia kofeiny (poziom bezpieczeństwa dla dzieci i młodzieży do $3 \mathrm{mg} / \mathrm{kg}$ m.c., dla dorosłych do $5,7 \mathrm{mg} / \mathrm{kg}$ m.c.), uznawany za bezpieczny.

Wnioski. Respondenci, którzy przekroczyli bezpieczną dawkę spożycia kofeiny, powinni ograniczyć spożycie produktów będących jej głównym źródłem (kawa).

Słowa kluczowe: kofeina, spożycie kofeiny z żywnościa, Polska, kobiety, mężczyźni

Corresponding author: Joanna Wyka, Department of Human Nutrition, Wroclaw University of Environmental and Life Sciences, Chełmońskiego 37, 51-630 Wrocław, Poland, e-mail:joanna.wyka@upwr.edu.pl 


\section{INTRODUCTION}

Caffeine is the most widespread psychoactive substance in the world. The purine alkaloid is present in coffee beans, tea leaves, cocoa beans, kola nuts (cola vera) and in nearly 60 species of other plants. Caffeine annual consumption is estimated at 120,000 tonnes $[17,30]$. In the daily food ration of a Central European resident, the content of this alkaloid ranges between 280-490 mg/day. In Sweden, the consumption of caffeine is greater, resulting from high consumption of coffee. Slightly less caffeine is consumed in the United States, where its average consumption ranges from 193 to $280 \mathrm{mg} /$ day. Polish people consume it relatively little - about $140 \mathrm{mg} /$ day [27]. Caffeine is used as an additive to non-alcoholic beverages in order to achieve a specific taste (eg. in cola). Caffeine is a component of energy drinks and slimming preparations. Through antagonistic influence, caffeine acts as a stimulant, maintains a period of wakefulness, increased mental performance, reduces and delays fatigue. Caffeine is primarily absorbed in the stomach, and, to a lesser extent, in the distal segments of the digestive tract. It is then transported to all tissues, including the brain. With long-term consumption of caffeinated beverages, there is a high probability of overtaking on caffeine, which is characterized by physical and mental disorders [10,15, 19, 20, 21, 24, 29]. Confirmation of the above conclusions is the opinion issued in 2015 by the European Food Safety Authority, EFSA (European Food Safety Authority) about a safe dose of caffeine intake by various population groups. It was found that the intake of a single dose of caffeine up to $200 \mathrm{mg}$ (about $3 \mathrm{mg} / \mathrm{kg}$ body weight of an adult with a body weight of $70 \mathrm{~kg}$ ) by an adult does not pose a threat to health and safety. In the case of habitual consumption of caffeine from all sources, the acceptable daily intake should not exceed $400 \mathrm{mg}$ for adults (approximately $5.7 \mathrm{mg} / \mathrm{kg}$ b.w. per day for $70 \mathrm{~kg}$ of an adult), with the exception of pregnant women. The habitual consumption of caffeine by pregnant women should be $200 \mathrm{mg} /$ day without risk to the fetus. EFSA proposes a level of up to $3 \mathrm{mg}$ of caffeine per kilogram of body weight per day (i.e. an individual caffeine level for adults) for regular consumption of caffeine by children and adolescents [5]. A significant increase in the interest of products containing caffeine is associated with western life style, the effect of exposure to the stimulus of advertising. Caffeine-rich products are consumed by a wide range of consumers in all age groups due to their stimulating effect and their high availability. They are very popular among young people, and more and more often among children due to their sweet taste (soft drinks, energy drinks) $[4,6,16,26]$.
The aim of the study was to estimate the consumption of caffeine in the daily food intake of Polish females and males, determine the share of selected products in the intake of this substance.

\section{MATERIALS AND METHODS}

The survey was completed by 433 respondents (pupils, students, workers, unemployed, and pensioners) living in Poland and willing to setup the questionnaire. The study was completed by means of a diagnostic survey using the CAWI (ComputerAssisted Web/Internet Interviewing) survey technique. A research technique in which the online survey is supervised by a computer system. Questionnaire questions are downloaded from the survey organizer's website and transmitted via the network to any point in which the respondent is located together with a computer connected to the Internet. A person examined in the CAWI system, alone or in the presence of an interviewer, reads the question content from the screen and provides answers that are recorded on the target server. Using a self-administered questionnaire, participants were asked questions regarding their socio- demographic characteristics (including gender, age, education, place of residence, type of professional activity), anthropometric measurements (weight, height), physical activity level (unsystematic physical activity, systematic physical activity, i.e. planned, structured, repeated physical activity for the purpose of maintaining or improving health, lack physical activity) and intake of caffeine-containing beverages (i.e. portion size and frequency of consumption of coffee, tea, cocoa, chocolate, energy drinks and colacarbonated beverages) $[11,13,18]$. For the needs of conducting the analyses, the respondents were divided into groups differentiated in terms of gender (females, males), age ( $\leq 18,19-30,31-50, \geq 51$ years), education (primary, vocational, secondary, higher) and place of residence (rural areas, urban areas), as well as declared physical activity (unsystematic, systematic, lack physical activity) and smoking (smoker, non-smoker). Each participant was asked to choose a product with caffeine and the portion that was consumed, and then determine the frequency of consumption of a given product. The following portion sizes were used: a) in the case of coffee, tea, cocoa and chocolate, the respondents entered the size of the portion (eg. 1 teaspoon $=2,5 \mathrm{~g}$ coffee beans, grounded, but $2.0 \mathrm{~g}$ instant coffee), regardless of the amount of infusion made from it; (b) in the case of beverages: a can with a capacity of $0.33 \mathrm{~L}$ or $0.25 \mathrm{~L}$ glass bottle with a capacity of $0.2 \mathrm{~L}$, plastic bottles according to the range, and the home measurement a glass of any indicated capacity from the range of 0.2 $\mathrm{L}$ to $0.5 \mathrm{~L}$. The frequency of consumption of products 
was determined by the following categories: daily ( 1 time, 2 times, 3 times, 4 times, 5 times 6 times), several times a week ( 1 time, 2 times, 3 times, 4 times, 5 times, 6 times), several times a month (once, twice, three times), less often than once a month and never. Th e study also took into account the type of tea and coffee (eg. tea: leaf/ granulated/express, green/black/red, coffee: ground/granular/instant/decaffeinated/from the coffee machine or mix) and the time of brewing tea (up to 1 minute, 1 minute, 5 minutes). Caffeine content in products was adopted on the basis of data from the literature on the subject and presented in Table $1[1,2$, $6,7,12,27,32]$.

The total daily caffeine intake by respondents was calculated according to the formula:

$$
\begin{aligned}
\operatorname{EDI}(\mathrm{mg} / \text { day })= & \mathrm{P} \cdot \mathrm{F} \cdot \mathrm{C} \text { or EDI }(\mathrm{mg} / \mathrm{kg} \text { b.w./day }) \\
& =(\mathrm{P} \cdot \mathrm{F} \cdot \mathrm{C}) / \mathrm{W}
\end{aligned}
$$

Where:

EDI - Estimated Daily Intake of caffeine

$\mathrm{P}$ - data on the portion size (number of spoons of a loose product or volume of a liquid product expressed in liters);

$\mathrm{F}$ - data on the frequency of consumption of portions per day

(multiplicity of intake per day, eg. 3 times per day: 3/1;

per week, eg. 5 times per week: 5/7;

per month, eg. 2 times per month: $2 / 30$ );

$\mathrm{C}$ - caffeine content in the product (taking into account the type of coffee and tea, brewing time), expressed in mg per teaspoon of loose product, $\mathrm{mg}$ per pack of finished product or $\mathrm{mg} / \mathrm{L}$ );

$\mathrm{W}$ - respondent's body weight ( $\mathrm{kg}$ b.w.).

\section{Example calculations:}

eg. for ground coffee, 1 teaspoon $=2.5 \mathrm{~g}$

$1.83 \mathrm{~g} / 100 \mathrm{~g}=1830 \mathrm{mg} / 100 \mathrm{~g}$

$1830 \mathrm{mg} / 100 \mathrm{~g}$ x $2.5 \mathrm{~g}=45.75 \mathrm{mg}$ ground coffee / 1 teaspoon

$\mathrm{EDI}=[2$ teaspoons of ground coffee $\mathrm{x} 2 / 1$ (two times per day) $\mathrm{x} 45.75 \mathrm{mg} / \mathrm{teaspoon}] / 60 \mathrm{~kg}$ b.w. $=3.05$ $\mathrm{mg}$ caffeine from ground coffee per $1 \mathrm{~kg}$ b.w.

$\mathrm{EDI}=($ liquid product expressed in $\mathrm{ml})=[1$ cup of coffee drink mix " 2 in1" (150 ml) x 1/1 (once per day) x $78 \mathrm{mg} / 150 \mathrm{ml}] / 65 \mathrm{~kg}$ b.w. $=1.2 \mathrm{mg}$ caffeine from cup of coffee drink mix "2in1" per $1 \mathrm{~kg}$ b.w.

The most frequent drinkers were brewed ground coffee, instant coffee and cappuccino, and among teas, black express tea. The obtained results were summed up and the average daily caffeine intake from all products included in the study was determined. Share of respondents exceeding daily caffeine intake (in \%) was assumed by EFSA opinion about safe dose of caffeine in children $3 \mathrm{mg} / \mathrm{kg}$ b.w. and in adults $5.7 \mathrm{mg} /$ $\mathrm{kg}$ b.w.

Table 1. Caffeine content of selected products $[1,2,6,7,12$,

\begin{tabular}{|c|c|}
\hline Source & $\begin{array}{l}\text { Mean caffeine } \\
\text { content }\end{array}$ \\
\hline \multicolumn{2}{|l|}{ Coffee } \\
\hline Ground coffee & $1.83 \mathrm{~g} / 100 \mathrm{~g}$ coffee \\
\hline $\begin{array}{c}\text { Coffee beans (ground before } \\
\text { brewing) }\end{array}$ & $2.27 \mathrm{~g} / 100 \mathrm{~g}$ coffee \\
\hline Instant coffee & $1.65 \mathrm{~g} / 100 \mathrm{~g}$ coffee \\
\hline Coffee drink mix “2in1” & $78 \mathrm{mg} / 150 \mathrm{ml}$ \\
\hline Coffee drink mix "3in1" & $54 \mathrm{mg} / 150 \mathrm{ml}$ \\
\hline Cappuccino chocolate & $39.0 \mathrm{mg} / 150 \mathrm{ml}$ \\
\hline Cappuccino peanut & $44.0 \mathrm{mg} / 150 \mathrm{ml}$ \\
\hline Cappuccino creamy & $41.0 \mathrm{mg} / 150 \mathrm{ml}$ \\
\hline Cappuccino with magnesium & $46.0 \mathrm{mg} / 150 \mathrm{ml}$ \\
\hline Coffee from the machine & $66 \mathrm{mg} / 150 \mathrm{ml}$ \\
\hline Espresso coffee & $100 \mathrm{mg} / 60 \mathrm{ml}$ \\
\hline Decaffeinated coffee & $0.1 \mathrm{~g} / 100 \mathrm{~g}$ coffee \\
\hline Decaffeinated instant coffee & $0.1 \mathrm{~g} / 100 \mathrm{~g}$ coffee \\
\hline \multicolumn{2}{|l|}{ Tea } \\
\hline Black express tea & $\begin{array}{c}14.9 \mathrm{mg} / \text { teabag/ } \\
200 \mathrm{ml} / 15 \mathrm{~second} \\
21.8 \mathrm{mg} / \mathrm{teabag} / \\
200 \mathrm{ml} / 1 \mathrm{minute}\end{array}$ \\
\hline Green express tea & $\begin{array}{l}22.0 \mathrm{mg} / \text { teabag/ } \\
200 \mathrm{ml} / 1 \mathrm{minute} \\
30.5 \mathrm{mg} / \text { teabag/ } \\
200 \mathrm{ml} / 5 \mathrm{minute}\end{array}$ \\
\hline Black leaf tea & $\begin{array}{c}33.5 \mathrm{mg} \text { teaspoon/ } \\
200 \mathrm{ml} / 5 \text { minute }\end{array}$ \\
\hline Green leaf tea & $\begin{array}{c}33.4 \mathrm{mg} / \text { teaspoon/ } \\
200 \mathrm{ml} / 5 \text { minute }\end{array}$ \\
\hline \multicolumn{2}{|c|}{ Energy drinks } \\
\hline Energy drinks & $80 \mathrm{mg} / 250 \mathrm{ml}$ \\
\hline \multicolumn{2}{|c|}{ Cocoa/chocolate } \\
\hline Cocoa/hot chocolate & $4-5 \mathrm{mg} / 150 \mathrm{ml}$ \\
\hline Milk chocolate & $20.8 \mathrm{mg} / 100 \mathrm{~g}$ \\
\hline Bitter chocolate & $66.5 \mathrm{mg} / 100 \mathrm{~g}$ \\
\hline \multicolumn{2}{|c|}{ Cola-type drinks } \\
\hline Coca-Cola & $9.4 \mathrm{mg} / 100 \mathrm{ml}$ \\
\hline Pepsi & $10.1 \mathrm{mg} / 100 \mathrm{ml}$ \\
\hline
\end{tabular}
$27,32]$

\section{Statistical analysis}

The hypothesis on the normal distribution of the analyzed variables was assessed using the ShapiroWilk test. Kruskal-Wallis ANOVA compared differences in caffeine intake among each group (age, gender, education, place of residence, physical 
activity, smoking). In addition, $\chi 2$ was performed to show a relationship between the number of people crossing the safe daily dose of caffeine and gender, age, education, place of residence, physical activity and smoking. All data were performed as mean, standard deviation (SD), median (Me), interquartile range (Q25-Q75) and percentage of participants exceed safe dose of caffeine. Statistical analysis was carried out using statistical program Statistica v.10.0. The level of significance was assumed at $\mathrm{p}<0.05$.

\section{RESULTS}

\section{Characteristics of respondents}

The characteristics of the respondents are presented in Table 2. 433 respondents completed the survey and were included in the analysis. The sample contained approximately equal number of men and women. Most of the respondents were aged 19-30.

Considering the nutritional status, the majority of respondents were characterized by normal BMI. Underweight was found in $9 \%$ of respondents. Almost every fifth respondents was overweight, and the BMI indicator for obesity was slightly more than $5 \%$ of respondents. Almost 50\% of respondents were characterized by secondary education. The highest percentage of respondents were workers. Among all respondents, a similar percentage of people declared a systematic or unsystematic physical activity. 3/4 of respondents are non-smokers. Most respondents inhabited urban areas.

Estimated total caffeine intake and the proportion of products in the consumption of caffeine

Table 3 shows total mean and the estimated relative total daily caffeine intake (mg/day) and the proportion of products in the consumption of caffeine. Total mean daily caffeine intake was $255.75 \mathrm{mg}$, and estimated relative total daily caffeine intake was $199.72 \mathrm{mg}$.

The amount of caffeine intake was statistically significantly determined by the type of product consumed $(p<0.0000)$. The respondents consumed the most caffeine when they consumed coffee. It accounted for $60.3 \%$ of the total intake, amounting to $154.32 \mathrm{mg}$ per day (median $43.64 \mathrm{mg}$ per day). Tea was also an important source of caffeine. Along with it, $70.12 \mathrm{mg}$ of caffeine were supplied (median $37.60 \mathrm{mg}$ ), and the contribution to intake was $27.4 \%$.

Assessment of caffeine intake by vs. sex, age, education, place of residence, smoking

The total mean daily caffeine intake per kilogram of body weight was $3.78 \mathrm{mg}$, and estimated relative total daily caffeine intake was $2.88 \mathrm{mg} / \mathrm{kg}$ b.w. Significant differences in relative total daily caffeine intake $(\mathrm{mg} /$ $\mathrm{kg}$ b.w.) by gender, age, education, and smoking status shown in Table 4. Females (mean: $4.27 \mathrm{mg} / \mathrm{kg}$ b.w.; median: $3.35 \mathrm{mg} / \mathrm{kg}$ b.w.) consumed more caffeine than males (mean: $3.29 \mathrm{mg} / \mathrm{kg}$ b.w.; median: $2.61 \mathrm{mg} /$ $\mathrm{kg}$ b.w.) $(\mathrm{p}=0.023)$.

The highest consumption of caffeine was observed among respondents between 31 and 50 years old (mean: $5.13 \mathrm{mg} / \mathrm{kg}$ b.w.; median: $4.62 \mathrm{mg} / \mathrm{kg}$ b.w.), and the lowest in adolescents under 18 years old (mean: 2.56 $\mathrm{mg} / \mathrm{kg}$ b.w.; median: $1.61 \mathrm{mg} / \mathrm{kg}$ b.w. $)(\mathrm{p}=0.0001)$. The

Table 2. Characteristics of respondents

\begin{tabular}{|c|c|c|}
\hline \multirow{2}{*}{$\begin{array}{l}\text { Variables } \\
\text { Total subject }\end{array}$} & $\mathrm{n}$ & $\%$ \\
\hline & 433 & 100 \\
\hline \multirow{2}{*}{$\begin{array}{c}\text { Gender } \\
\text { females } \\
\text { males }\end{array}$} & 218 & 50.3 \\
\hline & 215 & 49.7 \\
\hline \multirow{4}{*}{$\begin{array}{c}\text { Age (years) } \\
\leq 18 \text { (Me } 16.6 \mathrm{y} .) \\
19-30(\text { Me } 25.5 \mathrm{y} .) \\
31-50(\text { Me } 41.4 \mathrm{y} .) \\
\geq 51(\text { Me } 57.9 \mathrm{y} .)\end{array}$} & 58 & 13.4 \\
\hline & 293 & 67.7 \\
\hline & 65 & 15.0 \\
\hline & 17 & 3.9 \\
\hline \multirow{8}{*}{$\begin{array}{c}\text { Nutritional status by BMI } \\
<16 \\
16-16.99 \\
17-18.49 \\
18.5-24.49 \\
25-29.99 \\
30-34.99 \\
35-39.9 \\
\geq 40\end{array}$} & 1 & 0.2 \\
\hline & 3 & 0.7 \\
\hline & 35 & 8.1 \\
\hline & 287 & 66.3 \\
\hline & 84 & 19.4 \\
\hline & 15 & 3.5 \\
\hline & 4 & 0.9 \\
\hline & 4 & 0.9 \\
\hline \multirow{4}{*}{$\begin{array}{l}\text { Education } \\
\text { primary } \\
\text { vocational } \\
\text { secondary } \\
\text { higher }\end{array}$} & 65 & 15.0 \\
\hline & 19 & 4.4 \\
\hline & 202 & 46.7 \\
\hline & 147 & 33.9 \\
\hline \multirow{5}{*}{$\begin{array}{c}\text { Type of professional activity } \\
\text { pupils } \\
\text { student } \\
\text { workers } \\
\text { pensioner } \\
\text { unemployed }\end{array}$} & 62 & 14.3 \\
\hline & 157 & 36.3 \\
\hline & 164 & 37.9 \\
\hline & 15 & 3.5 \\
\hline & 35 & 8.0 \\
\hline \multirow{3}{*}{$\begin{array}{c}\text { Physical activity } \\
\text { unsystematic } \\
\text { systematic } \\
\text { lack }\end{array}$} & 175 & 40.4 \\
\hline & 183 & 42.3 \\
\hline & 75 & 17.3 \\
\hline \multirow{2}{*}{$\begin{array}{c}\text { Smoking } \\
\text { smoker } \\
\text { non-smoker }\end{array}$} & 99 & 22.9 \\
\hline & 334 & 77.1 \\
\hline \multirow{2}{*}{$\begin{array}{l}\text { Place of residence } \\
\text { rural areas } \\
\text { urban areas }\end{array}$} & 90 & 20.8 \\
\hline & 343 & 79.2 \\
\hline
\end{tabular}


Table 3. Estimated relative total daily caffeine intake (mg/day) and the proportion of products in the consumption of caffeine (in \%)

\begin{tabular}{|c|c|c|c|c|c|}
\hline Caffeine source & Mean \pm SD & $\%$ & Median & Q25-Q75 & p-value \\
\hline $\begin{array}{c}\text { Total caffeine } \\
\text { intake }\end{array}$ & $255.75 \pm 233.10$ & 100.0 & 199.72 & $78.42-370.47$ & $0-244.0$ \\
\hline Coffee & $154.32 \pm 223.72$ & 60.3 & $43.64^{\mathrm{a}}$ & $37.60^{\mathrm{b}}$ & $13.43-92.90$ \\
\hline Tea & $70.12 \pm 86.32$ & 27.4 & $0.30^{\mathrm{c}}$ & $0-0.76$ & $<0.0001$ \\
\hline Cocoa/Chocolate & $0.65 \pm 1.23$ & 0.3 & $1.33^{\mathrm{c}}$ & $0-6.67$ & \\
\hline Energy drinks & $14.31 \pm 43.96$ & 5.6 & $2.78^{\mathrm{c}}$ & $0.69-16.79$ & \\
\hline Cola-type drinks & $16.50 \pm 32.26$ & 6.4 & & \\
\hline
\end{tabular}

p-value - was calculated by analysis of variance Kruskal-Wallis ANOVA for $\mathrm{p}<0.05$;

$\mathrm{a}, \mathrm{b}, \mathrm{c}-$ statistically significant differences

Table 4. Estimated relative total daily caffeine intake ( $\mathrm{mg} / \mathrm{kg}$ b.w.)

\begin{tabular}{|c|c|c|c|c|}
\hline Variables & Mean \pm SD & Median & Q25-Q75 & \multirow{2}{*}{$\mathrm{p}$-value } \\
\hline total subject & $3.78 \pm 3.50$ & 2.88 & $1.21-5.10$ & \\
\hline $\begin{array}{l}\text { Gender } \\
\text { females }\end{array}$ & $4.27 \pm 4.02$ & $3.35^{\mathrm{a}}$ & $1.36-5.56$ & \multirow[t]{2}{*}{0.023} \\
\hline males & $3.29 \pm 2.80$ & $2.61^{b}$ & $1.06-4.87$ & \\
\hline $\begin{array}{c}\text { Age (years) } \\
\leq 18\end{array}$ & $2.56 \pm 2.38$ & $1.61^{\mathrm{a}}$ & $0.65-3.42$ & \multirow{4}{*}{0.0001} \\
\hline $19-30$ & $3.74 \pm 3.33$ & 2.85 & $1.24-4.98$ & \\
\hline $31-50$ & $5.13 \pm 4.43$ & $4.62^{b}$ & $2.01-6.65$ & \\
\hline$\geq 51$ & $3.68 \pm 2.47$ & 3.22 & $1.39-5.19$ & \\
\hline $\begin{array}{l}\text { Education } \\
\text { primary }\end{array}$ & $2.56 \pm 2.25$ & $1.49^{\mathrm{a}}$ & $0.67-3.11$ & \multirow{4}{*}{0.0002} \\
\hline vocational & $2.74 \pm 2.65$ & 1.12 & $0.29-4.71$ & \\
\hline secondary & $3.96 \pm 3.57$ & $2.99^{b}$ & $1.46-5.25$ & \\
\hline higher & $4.23 \pm 3.61$ & $3.70^{\mathrm{b}}$ & $1.35-5.66$ & \\
\hline $\begin{array}{c}\text { Place of residence } \\
\text { rural areas } \\
\end{array}$ & $4.27 \pm 3.56$ & 3.61 & $1.33-5.65$ & \multirow[t]{2}{*}{0.137} \\
\hline urban areas & $3.66 \pm 3.48$ & 2.78 & $1.19-4.95$ & \\
\hline $\begin{array}{c}\text { Physical activity } \\
\text { unsystematic }\end{array}$ & $3.55 \pm 3.16$ & 2.91 & $1.22-4.95$ & \multirow{3}{*}{0.299} \\
\hline systematic & $3.76 \pm 3.66$ & 2.69 & $1.06-5.54$ & \\
\hline lack & $4.39 \pm 3.84$ & 3.15 & $1.38-5.89$ & \\
\hline $\begin{array}{l}\text { Smoking } \\
\text { smoker }\end{array}$ & $5.36 \pm 4.00$ & $4.59^{\mathrm{a}}$ & $2.90-6.68$ & \multirow[t]{2}{*}{$<0.0001$} \\
\hline non-smoker & $3.32 \pm 3.20$ & $2.32^{\mathrm{b}}$ & $1.00-4.71$ & \\
\hline
\end{tabular}

p-value - was calculated by analysis of variance Kruskal-Wallis ANOVA for $\mathrm{p}<0.05$;

$\mathrm{a}, \mathrm{b}$ - statistically significant differences

daily caffeine intake among respondents with higher (mean: $4.23 \mathrm{mg} / \mathrm{kg}$ b.w.; median: $3.70 \mathrm{mg} / \mathrm{kg}$ b.w.) and secondary education (mean: $3.96 \mathrm{mg} / \mathrm{kg}$ b.w.; median: $2.99 \mathrm{mg} / \mathrm{kg}$ b.w.) was significantly higher compared to respondents with primary education (mean: 2.56 $\mathrm{mg} / \mathrm{kg}$ b.w.; median: $1.49 \mathrm{mg} / \mathrm{kg}$ b.w.) ( $=0.0002)$. The total caffeine intake among smokers (mean: 5.36 $\mathrm{mg} / \mathrm{kg}$ b.w.; median: $4.59 \mathrm{mg} / \mathrm{kg}$ b.w.) was significantly higher than non-smokers (mean: $3.32 \mathrm{mg} / \mathrm{kg}$ b.w.; median: $2.32 \mathrm{mg} / \mathrm{kg}$ b.w. $)(\mathrm{p}<0.0001)$.
Assessment of intake above (standard/agency) safe criteria

Percentage of respondents exceeding daily caffeine intake is shown in Table 5. Approximately $20 \%$ of respondents exceed the daily limit values of caffeine intake. Acceptable daily intake (habitual) of substances set at $5.7 \mathrm{mg} / \mathrm{kg}$ b.w., i.e. $400 \mathrm{mg} /$ day, was exceeded in $17.7 \%$ of the surveyed males and $22.5 \%$ of females. Caffeine consumers below 18 year were assumed by lowest level of caffeine intake according to EFSA opinion ( $3 \mathrm{mg} / \mathrm{kg}$ b.w). 
Table 5. Percentage of people exceeding daily caffeine intake (\%)

\begin{tabular}{|c|c|c|c|}
\hline Variables & $\mathrm{n}$ & $\%$ & \multirow{2}{*}{$\mathrm{p}$-value } \\
\hline total subject & 87 & 20.1 & \\
\hline $\begin{array}{c}\text { Sex } \\
\text { females }\end{array}$ & 49 & $22.5^{\mathrm{a}}$ & \multirow[t]{2}{*}{ a vs. b 0.259} \\
\hline males & 38 & $17.7^{\mathrm{b}}$ & \\
\hline $\begin{array}{c}\text { Age (years) } \\
\leq 18\end{array}$ & 5 & $8,6^{\mathrm{a}}$ & \multirow{4}{*}{$\begin{array}{l}\text { a vs. b } 0.074 \\
\text { a vs. c } 0.001 \\
\text { b vs. c } 0.008 \\
\text { b vs.d } 0.640 \\
\text { a vs. d } 0.934 \\
\text { c vs. d } 0.112\end{array}$} \\
\hline $19-30$ & 57 & $19.5^{b}$ & \\
\hline $31-50$ & 23 & $35.4^{\mathrm{c}}$ & \\
\hline$\geq 51$ & 2 & $11.8^{\mathrm{d}}$ & \\
\hline $\begin{array}{l}\text { Education } \\
\text { primary }\end{array}$ & 6 & $9.2^{\mathrm{a}}$ & \multirow{4}{*}{$\begin{array}{l}\text { a vs. b } 0.038 \\
\text { b vs. c } 0.751 \\
\text { b vs. d } 0.666 \\
\text { c vs. d } 0.866 \\
\text { a vs.d } 0.028\end{array}$} \\
\hline vocational & 3 & $15.8^{b}$ & \\
\hline secondary & 44 & $21.8^{\mathrm{c}}$ & \\
\hline higher & 34 & $23.1^{\mathrm{d}}$ & \\
\hline $\begin{array}{c}\text { Place of residence } \\
\text { rural areas }\end{array}$ & 22 & $24.4^{\mathrm{a}}$ & \multirow[t]{2}{*}{ a vs. b 0.337} \\
\hline urban areas & 65 & $18.95^{b}$ & \\
\hline $\begin{array}{c}\text { Physical activity } \\
\text { unsystematic }\end{array}$ & 28 & $16.0^{\mathrm{a}}$ & \multirow{3}{*}{$\begin{array}{c}\text { a vs. b } 0.201 \\
\text { b vs. c } 0.659 \\
\text { a vs. c }<0.0001\end{array}$} \\
\hline systematic & 40 & $21.9^{b}$ & \\
\hline lack & 19 & $25.3^{\mathrm{c}}$ & \\
\hline $\begin{array}{l}\text { Smoking } \\
\text { smoker }\end{array}$ & 34 & $34.3^{\mathrm{a}}$ & \multirow[t]{2}{*}{ a vs. b 0.0001} \\
\hline non-smoker & 53 & $15.9^{b}$ & \\
\hline
\end{tabular}

p-value - comparisons with $\chi 2, \mathrm{p}<0.05$;

$\mathrm{a}, \mathrm{b}, \mathrm{c}, \mathrm{d}$ - compare of averages

The respondents between 31 and 50 years old constituted the highest percentage of people who exceeded the dose considered as safe for healthy people. Considering respondents under 18 years old, for whom EFSA proposes a level of normal caffeine intake up to $3 \mathrm{mg} / \mathrm{kg} / \mathrm{day}$, the percentage of people who exceed daily intake is $8,6 \%$. The least respondents with primary education exceeded the dose of daily caffeine intake. Significantly more often respondents with lack of physical activity exceeded the daily dose of caffeine (25.3\%) than respondents with unsystematic physical activity $(16.0 \%)(\mathrm{p}<0.0001)$. Also, significantly more often smokers (34.3\%) exceed the dose of this substance than non-smokers $(15.9 \%)(\mathrm{p}=0.0001)$.

\section{DISCUSSION}

The median daily intake of caffeine among the respondents was estimated at $2.88 \mathrm{mg} / \mathrm{kg}$ b.w. (199.72 $\mathrm{mg} /$ day) and was confirmed by the literature data that the daily caffeine intake in Central Europe was in the range from 3 up to $7 \mathrm{mg} / \mathrm{kg}$ b.w. [4, 5]. A similar level of caffeine intake was determined by other authors [31, 32]. In American studies conducted on a representative sample of the population, the average caffeine intake was similar and amounted about 3.01 $\mathrm{mg} / \mathrm{kg}$ b.w., i.e. $211 \mathrm{mg} /$ day [8]. Similarly, in British studies conducted among women of childbearing age, the caffeine consumption was $173.9 \mathrm{mg} /$ day, i.e. approx. $3.0 \mathrm{mg} / \mathrm{kg}$ b.w. [3]. Whereas studies conducted in Austria [22] among adolescents and adults up to 40 years old, showed that the average caffeine intake was at a much higher level, i.e. $5.33 \mathrm{mg} / \mathrm{kg}$ b.w. Many studies it was support a hypothesis proved that caffeine intake by women per kilogram body weight was higher than for men. In Japanese studies [31] caffeine intake was $4.9 \mathrm{mg} / \mathrm{kg}$ in women, and $4.1 \mathrm{mg} / \mathrm{kg}$ b.w. in men. Whereas, in Austrian studies [22], the average caffeine intake in a woman was $5.4 \mathrm{mg} / \mathrm{kg}$ b.w./day, and in men $4.8 \mathrm{mg} / \mathrm{kg}$ b.w. Similar results were obtained in our these studies. Women consumed on $3.35 \mathrm{mg} / \mathrm{kg}$ b.w., and men $2.61 \mathrm{mg} / \mathrm{kg}$ b.w., and these differences were statistically significant. Analysing the caffeine intake in terms of age, there a statistically significant relationship was found between the amount of caffeine and age. The highest caffeine intake was consumed by respondents between 31 and 50 years old $(4.62 \mathrm{mg} / \mathrm{kg}$ b.w.), and the lowest by respondents under 18 years old (1.61 mg/kg b.w.). Fulgoni et al. [8] found that 31-50and 51-70-year-old people consumed approx. $3.05 \mathrm{mg} /$ $\mathrm{kg}$ b.w./day, and respondents below 19-year-olds 2,66 $\mathrm{mg} / \mathrm{kg}$ b.w./day. Rudolph et al. [22] recorded higher caffeine consumption with increasing age, where up to 25 years old the daily caffeine intake was $4.7 \mathrm{mg} /$ $\mathrm{kg}$ b.w., and above 25 years old was $5.8 \mathrm{mg} / \mathrm{kg}$ b.w. A study presented by Yamada et al. [31] conducted among the adults of Japanese community and the study of Tran et al. [25] conducted among American youth and young adults, as well as American and British studies conducted among young women aged 14-40 and 16-40 respectively 45 years also confirmed the observed trend of increasing the consumption of caffeine with age $[3,28]$. Also, in our own studies, it was recorded that after the age of 50, caffeine intake decreased and amounted $3.22 \mathrm{mg} / \mathrm{kg}$ b.w. A gradual decrease in caffeine consumption after the age of 50 was also noted by Knight et al. [14] (from $2.3 \mathrm{mg}$ to $1.92 \mathrm{mg} / \mathrm{kg}$ b.w./day). The lower level of caffeine intake among respondents over 50 years old may result from the decreasing amount of sleep needed with age, and thus the lack of need to regulate the daily rhythm with psychostimulants - the caffeine. Drinking coffee and smoking puts caffeine and nicotine at the top of the list of legally available psychoactive substances. Our research support a significant relationship between smoking and the amount of caffeine consumed. The total caffeine intake among smokers $(4.59 \mathrm{mg} / \mathrm{kg}$ b.w.) was significantly higher than among non-smokers $(2.32 \mathrm{mg} / \mathrm{kg}$ b.w.) $(\mathrm{p}<0.0001)$. Other researchers 
also indicated a similar relationship [3, 28]. Smokers consumed three times more caffeine than nonsmokers (approx. $5.40 \mathrm{mg} / \mathrm{kg}$ b.w./day vs. $1.79 \mathrm{mg} / \mathrm{kg}$ b.w./ day) [3]. In addition, along with increasing the dose of caffeine, the proportion of smokers increased, and decreased non-smokers consuming higher amounts of this substance (more than $200 \mathrm{mg} /$ day, i.e. approx. $2.86 \mathrm{mg} / \mathrm{kg}$ b.w./day) [28]. Every fifth of respondents, exceeded the level of acceptable daily caffeine intake set at $5.7 \mathrm{mg} / \mathrm{kg}$ b.w./day (i.e. $400 \mathrm{mg} /$ day). More often, this problem affected to females than males $(22.5 \%$ vs. $17.7 \%$ ) and respondents between 31 and 50 years old. In turn, lower than in the author's research, exceeding the acceptable daily a mount of caffeine intake by adult respondents was noted in the studies presented by Yamada et al. [31] in which this dose was exceeded by $15.4 \%$ of men and $10.8 \%$ of women. However, in the study of Wetmore et al. with the level of $200 \mathrm{mg} /$ day, the percentage of people with excessively high intake of this substance was higher (28\%) [28]. In contrast, $18 \%$ of women of childbearing age living in the United Kingdom exceeded the dose set at $300 \mathrm{mg} /$ day [3]. Knowing that respondents under 18 years old should not consume more than $3 \mathrm{mg} / \mathrm{kg}$ b.w./day of caffeine, the percentage of respondents who exceed the safe dose was noted at $32.8 \%$. In the studies of Santangelo et al. [23] even more teenagers, almost half (46\%) exceeded the upper limits of caffeine intake. Coffee was the richest source of caffeine in the diet of the respondents, and coffee contribution in caffeine intake was approximately $60 \%$. The same percentage of coffee in caffeine intake (60.8\%) was obtained by Rudolph et al. [22], who examined the adolescents and adults up to 40 years old. In turn, in the studies presented by Yamada et al. [31] showed the percentage of caffeine supplied with this product accounted only $47 \%$. Tea was also an important source of caffeine, the contribution was $27.4 \%$ of the total daily intake. In the studies of Yamada et al. [31] in groups of Japanese and Chinese that tea provided as much as $47 \%$ of caffeine. However, the highest share of tea in the collection of caffeine was recorded among the British 53\% [9].

\section{CONCLUSIONS}

Considering the average caffeine intake along with the diet, as well as the results of the health risk assessment resulting from exceeding the safe dose of caffeine intake among the studied population of Polish people, it is advisable to undertake all activities promoting health-oriented lifestyle and increasing consumer awareness in the field of nutritional knowledge. One of this maybe proper and healthy intake of caffeine as an chemo protective factor of nutrition. This fact was confirmed by the introduction of coffee as a drink that improves the health of the population in the Pyramid of Healthy Eating and Physical Activity by Institute of Food and Nutrition (IŻŻ) in 2016. In turn, among people who exceeded the safe dose of caffeine intake, the consumption of products that are its main source should be limited. It is also important to constantly monitor danger and conduct long-term research, which will significantly extend the knowledge of future generations. In addition, measures should be taken to regulate the descriptions provided by manufacturers on the packaging of products, including those food products in which caffeine is present. Thanks to this knowledge, consumers will be aware of their dietary choices.

\section{Conflict of interest}

The authors declare no conflict of interest.

\section{REFERENCES}

1. Białas, M., Łuczak, H., Przygoński, K.: Zawartość kofeiny w wybranych napojach kawowych w proszku. Brom. Chem. Toksykol. 2009, 42, 426-430.

2. Dąbrówka-Molenda, M., Szwedziak, K., Zabłudowska, $\dot{Z}$.: Analiza zawartości kofeiny w wybranych rodzajach kawy. Post. Tech. Przetw. Spoż. 2019, 2, 68-71.

3. Derbyshire, E., Abdula, S.: Habitual caffeine intake in women of childbearing age. J Hum Nutr Diet 2008; 21: 159-164.

4. Dworzański, W., Opielak, G., Burdan, F.: Undesirable effects of caffeine. Pol. Merkur. Lek. 2009;27:357-360.

5. EFSA NDA Panel (EFSA Panel on Dietetic Products, Nutrition and Allergies), 2015. Scientific Opinion on the safety of caffeine. EFSA Journal 2015; 13(5): 4102.

6. EFSAafactasheetsaonacaffeine.ahttp://www.efsa. europa.eu/en/corporate/pub/efsaexplainscaffeine 150527

7. Frankowski, M., Kowalski, A., Ociepa, A., et al. Caffeine levels in various caffeine-rich and decaffeinated coffee grades and coffee extracts marketed in Poland. Brom. Chem. Toksykol. 2008, 41, 21-27.

8. Fulgoni, V.L., Keast, D.R., Lieberman H.R.: Trends in intake and sources of caffeine in the diets of US adults: 2001-2010. Am J Clin Nutr 2015; 101: 1081-1087. doi:10.3945/ajen.113.080077.

9. Heatherley, S.V., Mullings, E.L., Tidbury, M.A., et al.: Caffeine consumption among a sample of UK adults. Appetite 2006; 47: 257-259, doi:10.1016/j. appet.2006.07.031.

10. Higdon J.V., Frei B.: Coffee and Health: A Review of Recent Human Research. Crit Rev Food Scien Nutr 2006; 46(2): 101-123.

11. https://www.linkedin.com/pulse/methodologiescompared-advantages-disadvantages-data-via-mancini [cit. 16. 7. 2018].

12.Jarosz, M., Wierzejska, R., Mojska, H. et al. Caffeine content in foodstuffs. Brom. Chem. Toksykol. 2009;43:776-781.

13. Knapik J.J., Austin K. G., McGraw S. M., Leahy G.D., Lieberman H.R.: Caffeine consumption among active 
duty United States Air Force personnel. Food Chem Toxicol 2017; 105: 377-386.

14. Knight, C.A., Knight, I., Mitchell, D.C., et al.: Beverage caffeine intake in US consumers and subpopulations of interest: estimates from the Share of Intake Panel survey. Food Chem Toxicol 2004; 42:1923-1930, doi:10.1016/j.fct.2004.05.002.

15. Kohler, M., Pavy, A., van Den Heuvel, C.: The effects of chewing versus caffeine on alertness, cognitive performance and cardiac autonomic activity during sleep deprivation. J Sleep Res 2006;15:358-368.

16. Mackus M., Van de Loo A.J.A.E., Benson S., Scholey A., Verster J.C.: Consumption of caffeinated beverages and the awareness of their caffeine content among Dutch students. Appetite 2016;103:353-357.

17. Mandel, H.G.: Update on caffeine consumption, disposition and action. Food Chem Toxicol 2002;40:12311234.

18. Mitchell D.C., Knight C.A., Hockenberry J., Teplansky R., Hartman T.J.: Beverage caffeine intakes in the U.S. Food Chem Toxicol 2014 63:136-142.

19. Nawrot P., Jordan S., Eastwood J., Rotstein J., Hugenholtz A., Feeley M.: Effects of caffeine on human health. Food Addit Contam 2003;20(1):1-30.

20. Ozsungur, S., Brenner, D., El-Sohemy, A.: Fourteen well described caffeine withdrawal symptoms factor into three clusters. Psychopharmacology 2009;201:541548.

21. Pelczyńska M., Bogdański P.: Prozdrowotne właściwości kawy. Forum Zaburzeń Metabol. 2019;10(3):112120.

22. Rudolph, E., Faerbinger, A., Koenig, J.: Caffeine intake from all sources in adolescents and young adults in Austria. Eur J Clin Nutr 2014; 68: 793-798, doi:10.1038/ ejcn.2014.50.

23. Santangelo, B., Lapolla, R., Rutigliano, I., et al.: Nearly half of the adolescents in an Italian school based study exceeded the recommended upper limits for daily caffeine consumption. Acta Paediatr 2018;107:10551059, doi:10.1111/apa.14277.

24. Suteerapataranon, S., Butsoongnern, J., Punturat, P., at al.: Caffeine in Chiang Rai tea infusions: Effects of tea variety, type, leaf form, and infusion conditions. Food Chem 2009; 114: 1335-1338.

25. Tran, N.L., Barraj, L.M., Bi, X., et al.: Trends and patterns of caffeine consumption among US teenagers and young adults, NHANES 2003-2012. Food Chem Toxicol 2016;94:227-242, doi:10.1016/j.fct.2016.06.007.

26. Wanat, G., Woźniak-Holecka, J.: Assessment of consumption of caffeine-containing products among university students and secondary school pupils. Probl. Hig. Epidemiol. 2011;92:695-699.

27. Wierzejska R.: Caffeine - common ingredient in a diet and its influence on human health. Rocz Panstw Zakl Hig 2012;63:141-147.

28. Wetmore, C.M., Ichikawa, L., LaCroix, A.Z., et al.: Association between caffeine intake and bone mass among young women: potential effect modification by depot medroxyprogesterone acetate use. Osteoporosis Int 2008;19:519-527, doi:10.1007/s00198- 007-0473-2.

29. Wikoff, D., Welsh, B.T., Henderson, R., et al.: Systematic review of the potential adverse effects of caffeine consumption in healthy adults, pregnant women, adolescents, and children. Food Chem Toxicol 2017;109:585-648, doi:10.1016/j.fct.2017.04.002

30. Wolde T: : Effects of caffeine on health and nutrition. A review. Food Sci Qual Manage 2014;30:1-9.

31. Yamada, M., Sasaki, S., Murakami, K., et al.: Estimation of caffeine intake in Japanese adults using $16 \mathrm{~d}$ weighed diet records based on a food composition database newly developed for Japanese populations. Public Health Nutr 2010;13:663-672.

32. Żary-Sikorska E.,Czok, H.: Estimation the intake of caffeine with the daily food ration in selected population group. In: Designed food Part III. Walczycka, M., Jaworska, G., Duda-Chodak, A., Tarko T. (eds.), Publisher: Oddział Małopolski Polskiego Towarzystwa Technologów Żywności, Kraków, Poland, 2011, pp. 5974, ISBN: 978-83-932389-2-7.

Received: 02.06.2021

Accepted:19.07.2021

Published online first: 23.07.2021 